Nadwa | Jurnal Pendidikan Islam

Vol. 11, Nomor 2 Tahun 2017

\title{
Marah Dalam Pendidikan Islam
}

\author{
Nasirudin \\ UIN Walisongo \\ nasirudin@walisongo.ac.id
}

\begin{abstract}
This paper is motivated by the humanity dimension of the Prophet s.a.w when angry. Hadiths indicate that the Prophet s.a.w. as uswah khasanah had experienced an attitude of anger and full of educational values. The purpose of this paper is to attempt to reveal the anger situation of the Prophet s.aw. and its implications in Islamic education. The results of the study found that the cause of the Prophet's anger s.a.w in general is an effort to maintain the sanctity of Islamic law. Then the angry implications that allowed in the educational process in the hadith perspective are (1). anger that does not hurt feelings or physical learners(2). Angry as a form of tactics to educate in difficult student conditions, (3). Angry who does not aim to take revenge on personal matters. All forms of anger must be accompanied by an explanation to be understood as a form of education.
\end{abstract}

Keywords: Angry; Hadith; Implications; Islamic education;

\begin{abstract}
Abstrak
Tulisan ini dilatarbelakangi oleh dimensi kemanusian Nabi s.a.w ketika marah. Hadits-hadits menunjukkan bahwa Nabi s.a.w. sebagai uswah khasanah pernah mengalami sikap marah dan penuh dengan nilai-nilai pendidikan. Tujuan tulisan ini adalah berupaya mengungkap gambaran kemarahan Nabi s.aw. dan implikasinya dalam pendidikan Islam. Hasil kajian menemukan bahwa penyebab kemarahan Nabi s.a.w pada umumnya merupakan upaya menjaga kesucian syariat Islam. Kemudian implikasi marah yang diperbolehkan dalam proses pendidikan dalam perspektif hadits adalah (1). marah yang tidak menyakiti perasaan ataupun fisik peserta didik (2). Marah sebagai bentuk taktik untuk untuk mendidik dalam kondisi siswa yang susah dikendalikan, (3). Marah bertujuan menyelamatkan dari azab di dunia dan akhirat, (4). Marah yang tidak bertujuan untuk membalas dendam karena persoalan pribadi. Semua bentuk kemarahan harus disertai dengan penjelasan agar dapat dipahami sebagai bentuk pendidikan.
\end{abstract}

Keywords : Marah; Hadits; Implikasi; Pendidikan Islam;

ISSN 1979-1739 (P) ; ISSN 2502-8057 (E).

(C) 2017 Nadwa | UIN Walisongo

http://journal.walisongo.ac.id/index.php/nadwa 


\section{Pendahuluan}

Tidak dapat dipungkiri bahwa tuntuan profesionalitas pendidik tidak dapat menghilangkan dimensi kemanuisannya. Hal ini dikarenakan dimensi kemnasuian seorang pendidik inhern atau menyatu dalam diri seorang penddik. Dimenasi kemanusia yang sering muncul dari seorang pendidik dalam dunia pendidikan adalah sikap marah (ghadzab). Marah adalah sifat manusiawi yang ada pada manusia disamping akal, hati dan syahwat. Marah di satu sisi bisa sebagai potensi yang mengarah pada sikap positif dan di sisi lain dapat mengarah pada sikap yang negatif.

Seorang pendidik dalam berinteraksi dengan peseta didik pasti akan menemukan berbagai macam kondisi. Keragaman kondisi tentu akan menentukan pola komunikasi dengan peserta didik. Kapan seorang pendidik bersikap lemah lembut, kapan pendidik bersikap tegas dan kapan pendidik boleh marah. Sikapsikap itu tentu disesuaikan dengan kondisi-kondisi yang ada. Dan yang terpenting adalah bahwa sikap-sikap itu harus dalam kerangka mendidik.

Dalam kontek Islam, Pendidikan Islam merupakan pendidikan yang dipahami dan dikembangkan serta disusun dari ajaran dan nilai-nilai fundamental yang terkandung dalam sumber dasarnya yaitu al-Qur’an dan al-Sunnah/hadīis. ${ }^{1}$ Oleh karena itu model dan pola komunikasi pendidikan Islam harus mencontoh Nabi saw. peranannya sebagai muallim (pendidik). Perkataan maupun perbuatan Nabi saw. adalah model dari pendidikan Islam.

Nabi saw. adalah seorang mualim yang sangat ideal digambarkan oleh seorang sahabat yang bernama Muawiyah bin al-Hakam,

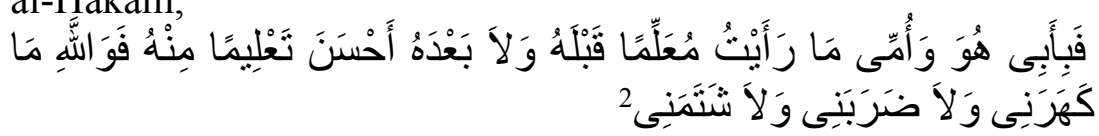

${ }^{1}$ Muhaimin, Pengembangan Kurikulum Pendidikan Agama Islamdi sekolah, Madrasah, dan Perguruan tinggi, (Jakarta : PT Raja Grafindo Persada, 2005), h. 7.

${ }^{2}$ Muslim, Șahīh Muslim,Juz 2, (al-Maktabah al-Syāmilah, al-Maktabah al-Ta'āwunī wa al-Da'wah bi al-Rauḍah, t.th.), h. 70. 
Demi ayah dan bundaku tidak pernah aku melihat seorang pendidik lebih baik dari pada beliau, baik sebelum maupun sesudahnya. Demi Allah beliau tidak membentak, memukul maupun memaki saya.

Nabi sebagai manusia yang mempunyai sifat-sifat manusia pada umumnya (al-arad al-Basyariyyah) pasti dapat tertawa, tersenyum dan marah ketika berhadapan dengan para sahabat yang hitorogen baik tingkat intelegensi, keagamaan, ekonomi, watak, kecenderungan dan lain sebagainya. Dalam kontek inilah penulis ingin membahas bagaimana sebenarnya sikap marah dalam perspektif hadìi yang kemudian dapat diterapkan dalam proses pendidikan. Karena hadīis sebagai segala sesuatu yang disandarkan kepada nabi Muhammad saw. baik perkataan, perbuatan maupun ketetapannya ${ }^{3}$ dan dijadikan sebagai sumber kedua setelah al-Qur’an, maka marah dalam perspektif ḥadīi Nabi saw. merupakan keniscayaan.

Penulis menganggap bahwa pembahasan ini sangat penting karena literatur tentang hadīis tarbawī (ḥadīis pendidikan), yang merupakan salah satu mata kuliah utama di program Pendidikan agama Islam (PAI), masih sangat sedikit. Hadīis tematik yang cukup banyak seperti ḥadīं aḥkām (ḥadīis tentang hukum), ḥadīì akhlak dan hadìs akidah. Dengan demikian pembahasan ini akan sangat memberikan konstribusi dalam bidang keilmuan pendidikan dan juga membantu para pengajar hadīs tarbawì.

\section{Marah Dalam Diskursus \\ Pengertian Marah}

Marah dalam bahasa Indonesia berarti sangat tidak senang, mungkin karena dihina, diperlakukan tidak sepantasnya dan lain sebagainya. ${ }^{4}$ Marah dalam bahasa Arab ering diterjemahkan dengan kata gạ̣ab. Abū Hāamid al-Gazālī mendefinisikan gaḍab sebagai berikut;

$$
5
$$

Bergejolaknya darah jantung karena menuntut pembalasan

${ }^{3}$ Rahmat Syafe,I, Ilmu Ushul Fiqh Untuk IAIN, STAIN dan PTAIS, (Bandung, CV.Pustaka Setia)., h. 60.

${ }^{4}$ http://artikata.com/arti-339835-marah.html

${ }^{5}$ Abū Hāmidal-Gazālī, Ihyā Ulūm al-Dīn, (Bairūt, Dār al-Ma'ārif,)., h. 163. 
Sementara Fālị̣ bin Muḥammad bin Fāliḥal-Ṣagīr mengatakan,

6 ثوران في النفس يحملها على الرغبة في البطش والانتقام

Suatu gejolak di dalam jiwa yang membawanya pada semangat memukul dan membalas

Dengan demikian marah dapat didefinisikan sebagai suatu gejolak jiwa untuk menangkal gangguan sebelum terjadi atau untuk mengobati dan membalas setelah terjadinya gangguan tersebut.Marah mengandung beberapa unsur, pertama, gejolak jiwa yang ditandai dengan darah naik, kedua, menagkal gangguan atau membalas gangguan dan ketiga, ekspresi lahir. Rasa marah menjadi suatu perasaan yang dominan secara perilaku, pengetahuan maupun fisik ketika seseorang mengambil pilihan secara sadar untuk bertidak dalam rangka menghentikan secara langsung ancaman yang datang dari luar. Marah merupakan pola perilaku yang didesain untuk memperingatkan pengganggu agar menghentikan perilaku yang dapat mengancam. Di antara ekspresi marah adalah bentuk raut muka, bahasa tubuh dan respon kejiwaan dan terkadang tindakan agresif. Ekspresi lainnya adalah mengeluarkan suara keras, sebagai upaya agar tampak lebih besar secara fisik, memamerkan gigi serta melotot.

Adapun macam-macam marah sebagaimana disampaikan Athiyah bin Muhammad Sālim dalam Syarah al-Arba'īn alNawawiyyah mengatakan bahwa macam-macam marah itu ada tiga yaitu marah hijau, marah merah dan marah hitam. ${ }^{7}$ Marah hijau itu merupakan marah yang terpuji dan diperlukan. Marah ini terjadi ketika larangan Allah dilanggar. Marah merah merupakan marah terhadap hal-hal sepele namun masih dalam batas kemampuan mengendalikan. Marah hitam merupakan marah yang membutakan mata batin dan membutakan mata lahir, sehingga orang yang marah ini kehilangan akal dan tidak tahu apa yang diperbuat. Dan pada ahirnya marah ini akan membahayakan diri pelakunya.

${ }^{6}$ Fāliḥ bin Muhammad bin Fāliḥal-Ṣagīr, Lā tagḍa Dirāisah Hadīsìyyah Da'awiyyah Nafsiyyah, (al-Maktabah al-Syāmilah, al-Maktabah al-Ta'āwunī wa al-Da'wah bi al-Raudah, t.th.), h. 4.

${ }^{7}$ Ațiyah bin Muhammad Sālim, Syaraḥ al-Arba'̄n al-Nawawiyyah, Juz 40., (al-Maktabah al-Syāmilah, al-Maktabah al-Ta'āwun̄̄ wa al-Da'wah bi alRauḍah, t.th.)., h. 14. 
Ada juga yang membagi marah dengan marah terpuji dan marah tercela. ${ }^{8}$ Marah terpuji merupakan marah karena Allah atau menjaga kemulianNya, seperti serangan terhadap aqidah, atau pembunuhan terhadap jiwa seorang muslim, pengambilan harta tanpa haknya, penyerobotan atas tanah, merusak kehormatan dan beredarnya kemaksiatan dan hal-hal yang dilarang oleh agama. Marah seperti ini didasar pada firman Allah,

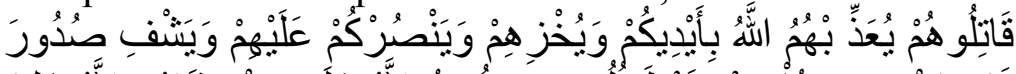

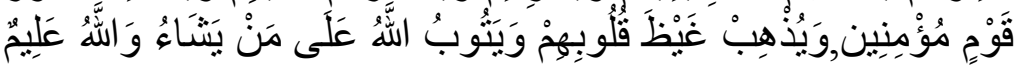

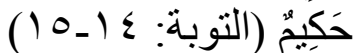

Perangilah mereka, niscaya Allah akan Menyiksa mereka dengan (perantaraan) tanganmu dan Dia akan Menghina mereka dan Menolongmu (dengan kemenangan) atas mereka, serta melegakan hati orang-orang yang beriman,dan Dia Menghilangkan kemarahan hati mereka (orang Mukmin). Dan Allah Menerima tobat orang yang Dia Kehendaki. Allah Maha Mengetahui, Maha Bijaksana (Q.S. al-Taubat: 14-15)

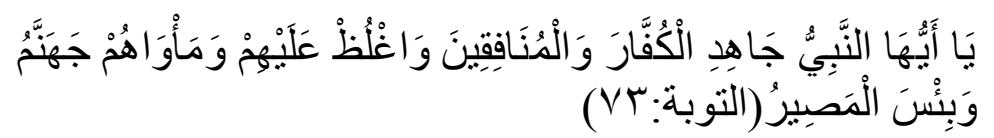

Wahai Nabi! Berjihadlah (melawan) orang-orang kafir dan orang-orang munafik, dan bersikap keraslah terhadap mereka. Tempat mereka adalah neraka Jahannam. Dan itulah seburuk-buruk tempat kembali (Q.S. alTaubat: 73)

Sedangkan marah tercela adalah marah sebagai balasan untuk membela diriNya. Marah ini sangat berbahaya untuk diri sendiri dan orang lain. Dan marah ini yang diperingatkan oleh Nabi dalam beberapa hadīis. Oleh karena itu, seyogyanya seseorang tidak perlu marah ketika dirinya yang dihina atau dirinya didhalimi.

Marah oleh al-Gazālī dianggap sebagai sebuah kekuatan. Oleh karena itu, pelakunya dapat diklasifikasikan menjadi tiga katagori, kendor (al-tafrit $)$, moderat (al-i'tidāl)_dan berlebihan (al-ifrät). Kendor (al-tafrit $)$ merupakan ungkapan akan hilangnya kekuatan marah. Sikap ini termasuk tercela. Padahal Allah mensifati para sahabat Nabi dengan

${ }^{8}$ Fālị̣ bin Muḥammad bin Fāliḥal-Ṣagīr, Lā tagḍab., h. 6. 


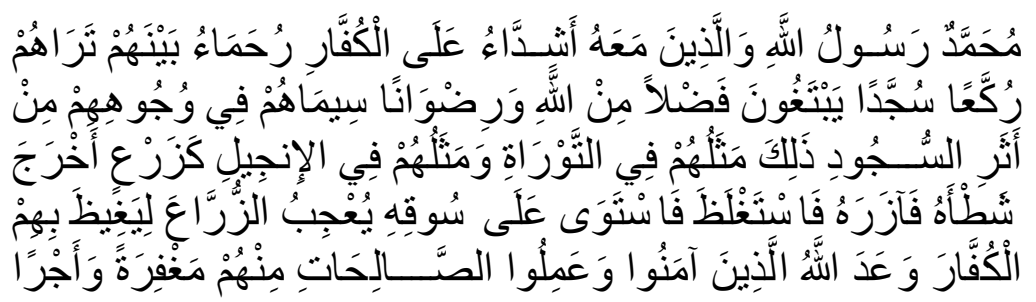

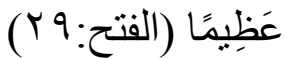

Muḥammad adalah utusan Allah, dan orang-orang yang bersama dengan dia bersikap keras terhadap orang-orang ka-fir, tetapi berkasih sayang sesama mereka. Kamu melihat mereka rukuk dan sujud mencari karunia Allah dan keridaan-Nya. Pada wajah mereka tampak tanda-tanda bekas sujud. Demikianlah sifat-sifat mereka (yang diungkapkan) dalam Taurat dan sifat-sifat mereka (yang diungkapkan) dalam Injil, yaitu seperti benih yang mengeluarkan tunasnya, kemudian tunas itu semakin kuat, lalu menjadi besar dan tegak lurus di atas batangnya; tanaman itu menyenangkan hati penanam-penanamnya, karena Allah hendak Menjengkelkan hati orang-orang kafir (dengan kekuatan orang-orang Mukmin). Allah Menjanjikan kepada orang-orang yang beriman dan mengerjakan kebajikan di antara mereka, ampunan dan pahala yang besar (Q.S. al-Fath: 29)

Moderat (al-i'tidal) merupakan ungkapan akan pertengahan sikap marah. Sikap ini sangat positif. Sikap marah ini dapat melahirkan sifat-sifat positif seperti syajāah (keberanian), hilm (menahan marah), teguh pendirian dan sayang. Orang yang mengembangkan potensi marah namun tidak sampai berlebihan akan menjadikan dirinya sebagai orang yang berani untuk menyatakan kebenaran, mampu menahan kemarahan sehingga tidak mudah membalas atas kedhaliman orang lain dan akan lebih mudah menyayangi orang lain.Marah adalah suatu pola perilaku yang dirancang untuk memperingatkan pengganggu untuk menghentikan perilaku mengancam mereka

Sedangkan berlebihan (al-ifrāt) adalah sebuah ungkapan tentang sikap marah yang berlebihan. Sikap ini sangat tercela. Pemilik sifat ini dapat keluar dari kebijaksanaan pikiran, ketaatan terhadap agama dan tidak akan muncul sebuah pertimbangan dan kedalaman penglihatan hati. Pengembangan sikap marah yang berlebihan seperti ini akan memunculkan sikap-sikap negatif seperti tahawur (nekad), ujub (bangga diri) dan takabbur (sombong)

Disisi lain Kemarahan bisa juga bermanfaat, ia merupakan suatu emosi alamiah yang dialami oleh semua manusia pada suatu 
waktu, dan memiliki nilai fungsional untuk kelangsungan hidup, mempertahankan kehormatan, harta, dan agama. Dengan kekuatan gadab (marah), jihad diperintahkan dan kehormatan diri terjaga. Dengan kekuatan marah pula seorang wanita menolak untuk dinodahi agama dan kehormatannya. Dengan kekuatan marah seseorang juga dapat menumpas kedhaliman dan kemunkaran.

\section{Proses Pendidikan Isam}

Pendidikan dalam bahasa Arab diterjemahkan dengan "tarbiyah" dari kata kerja rabbāyurabbìyang berarti mengembangkan. Dan dalam bahasa Yunani pendidikan diterjemahkan dengan paedagogic yang berarti bimbingan yang diberikan kepada anak. Istilah ini kemudian diterjemahkan ke dalam bahasa Inggris dengan education yang berarti pengembangan atau bimbingan. ${ }^{9}$ Dari kata "pengembangan atau bimbingan" ini muncul beberapa pertanyaan, siapa yang mengembangkan, siapa yang dikembangkan, apa yang dikembangkan dan untuk apa dikembangkan. Pertanyaanpertanyaan ini pada ahirnya akan dijawab dalam sebuah kalimat yang disebut definisi.

Ada beberapa rumusan tentang definisi pendidikan. pendidikan adalah proses pengembangan individu secara menyeluruh (jasmani, ruhani, aqliyah) di tengah-tengah masyarakatnya. ${ }^{10}$ Menurut Abdurrahman al-Bani yang dikutip oleh Abdurrahman an-Nahlawi bahwa pendidikan tercakup tiga unsur yaitu menjaga dan memelihara anak, mengembangkan bakat dan potensi anak sesuai dengan kekhasan masing-masing dan mengarahkan potensi dan bakat agar mencapai kebaikan dan kesempurnaan. Seluruh proses di atas dilakukan secara bertahap sesuai dengan konsep sedikit demi sedikit atau perilaku demi perilakunya. ${ }^{11}$ Adapun Menurut Ahmad D Marimba, pendidikan meliputi lima aspek, yaitu : 1) usaha (kegiatan); usaha itu bersifat I, h. 1

${ }^{9}$ Rumayis, Ilmu Pendidikan Islam, (Jakarta : Kalam Mutiara, 1994)., cet.

${ }^{10}$ Sayid Ibrahim al-Jabbar, al-Taujih al-Falsafi wa al-Ijtima'i li alTarbiyah,(Maktabah Gharib)., h. 36

${ }^{11}$ Abdurrahman an-Nahlawi, op. cit., h. 21 
bimbingan (pimpinan/ pertolongan) dan dilakukan secara sadar, 2) ada pendidik, pembimbing atau penolong, 3) ada yang didik atau si terdidik, 4) bimbingan itu mempunyai dasar dan tujuan, 5) dalam usaha itu tentu ada alat-alat yang dipergunakan. ${ }^{12}$

Dari beberapa definisi di atas dapat disimpulkan bahwa pendidikan merupakan sebuah bantuan kepada peserta didik untuk mengembangkan potensi-potensi yang dimiliki menuju kesempurnaan melalui pengasuhan, pemeliharaan dan penanaman.

Konsep pendidikan tidak hanya mencakup mengembangkan potensi yang dimiliki oleh anak-anak saja. Pendidikan secara lebih luas bisa mencakup potensi yang dimiliki oleh manusia yang membentang dari sejak lahir bahkan ada yang mengatakan pranatal hingga ke liang lahat. Dengan demikian pendidikan mengalami perluasan makna dari yang terbatas pada anak-anak sampai pada orang dewasa. Sehingga bayak ditemukan istilah pendidikan tinggi dimana peserta didiknya mereka yang sudah dewasa.

Konsep tarbiyah mencakup aspek ta'lim yakni proses transfer of knowledge, mahārah atau ketrampilan dan aspek ta ${ }^{\prime} \bar{\imath} b$ yakni proses pembentukan sikap. Konsep ta'lìm (transfer of knoledge) merupakan proses seumur hidup (min al-Mahdi ilā al-Lahdi ).

Pendidikan berproses menuju tujuan yang dicita-citakan. Tujuan yang akan dicapai setelah peserta didik menyelesaikan jenjang pendidikan tertentu memerlukan beberapa tahun untuk mencapainya. Tujuan yang akan dicapai setelah peserta didik menyelesaikan tingkat kelas tertentu memerlukan beberapa bulan untuk mencapainya. Dan Tujuan yang akan dicapai setelah peserta didik menyelesaikan pokok bahasan tertentu memerlukan beberapa jam untuk mencapainya.

Tujuan pendidikan, baik dalam skala pendek maupun panjang pasti memerlukan sebuah proses. Dalam sebuah proses tentu ada aktvitas yang dilakukan oleh peserta didik dibawah bimbingan seorang pendidik. Peran pendidik dapat berfungsi sebagai motivator, mediator, fasilitator, instruktur dan model.

\footnotetext{
${ }^{12}$ Ahmad D Marimba, Pengantar Filsafat Pendidikan Islam, (Bandung : PT al-Ma'arif, 1980), cet. IV, h. 19
} 
Seorang pendidik diharapkan mampu memberikan semangat kepada peserta didik untuk senantiasa belajar dan mengembangkan segala potensinya untuk mencapai tujuan. Sebagai mediator, seorang pendidik diharapkan bisa menjadi peratara yang mengantarkan segala pesan kepada peserta didik. Sebagai fasilitator, seorang pendidik diharapkan memberikan fasilitas terjadinya proses pembelajaran. Sebagai instruktur, seorang pendidik memberikan instruksi-instruksi kepada peserta didik agar terjadi pengalaman belajar. Dan sebagai model, segala apa yang terpancar ke dalam bahasa tubuh seorang pendidik dapat memberikan makna positif bagi peserta didik.

\section{Komunikasi Dalam Proses Pendidikan}

Komunikasi adalah sebuah "proses penyampaian makna dalam bentuk gagasan atau informasi dari seseorang kepada orang lain melalui media tertentu". ${ }^{13}$ Adapun Komunikasi pendidikan adalah "komunikasi yang terjadi dalam suasana pendidikan". ${ }^{14}$ Berdasar pengertian tersebut, komunikasi pendidikan dapat artikan sebagai sebuah proses penyampaian pesan oleh pendidik kepada peserta didik melalui simbol-simbol tertentu baik berupa kata-kata (verbal) maupun yang tidak berupa kata-kata (non verbal) guna mencapai tujuan yang telah direncanakan. Simbol kata-kata dapat berupa kata secara lisan maupun secara tertulis. sedangkan simbol tidak berupa kata-kata dapat berupa dapat berupa perbuatan (performance) maupun isyarat anggota badan.

Komunikasi pendidikan pada hakikatnya merupakan sebuah usaha pendidik untuk mempengaruhi secara efektif pada peserta didik (target person) agar terjadi perubahan tingkah laku (behavior) baik pengetahuan, ketrampilan maupun sikapnya. Untuk mempengaruhi orang lain atau peserta didik, Gary Yukl, seorang profesor dari university at Albany, Amerika serikat menggagas sebuah teori yang disebut Influence Behavior Questioniare (IBQ). ${ }^{15}$ Meskipun bersifat general, teori ini dapat

\footnotetext{
${ }^{13}$ Ngainun Naim, Dasar-Dasar Komunikasi Pendidikan, (Yogyakarta: Ar-ruzz Media, 2011), h. 18.

${ }^{14}$ Ibid., h. 27.

${ }^{15}$ Ibid.,h. 120.
} 
dikembangkan pada bidang-bidang khusus seperti bidang pendidikan.

IBQ (Influence Behavior Questioniare) meumuskan sembilan strategi dan teknik dalam mempengaruhi orang lain.

1. Rasional Persuasion, yaitu teknik mempengaruhi orang lain dengan menggunakan argumen logis dan rasional. teknik ini dipakai pendidik dengan memberikan penjelasan meteri yang diajarkan dengan argumentasi yang masuk akal dan meyakinkan.

2. Inspiration Appeals Tactics, yaitu siasat dengan meminta ide untuk mengembangkan rasa antusias dan semangat dari target person. Teknik ini akan memberikan dorongan kepada peserta didik untuk berfikir, mengembangkan inisiatif dan semakin bergairah dalam menekuni materi.

3. Consultation Tactics, yaitu teknik dengan cara meminta target person untuk ikut serta secara aktif dalam suatu aktivitas yang diagendakan.

4. Ingratiation Tactics, yaitu mempengaruhi target person dengan cara menyenangkan dan mententramkan hatinya.

5. Personal Appeals Tactic, yaitu metode di mana seorang pendidik dengan landasan hubungan persahabatan dan hal-hal yang sifatnya personal. Keeratan akan memudahkan pendidik mempengaruhi pesrta didik.

6. Exchange Tactics, yaitu suatu teknik yang mirip dengan Personal Appeals Tactic akan tetapi hubungan ini bukan didasarkan pada personal akan tetapi lebih mementingkan pada adanya pertukaran pemahaman.

7. Coalition Tactics, yaitu suatu metode di mana seorang pendidik bekerja sama (coalition) dan meminta pertolongan pihak lain untuk ikut mempengaruhi peserta didik.

8. Pressur Tactic, yaitu suatu motode dalam mempengaruhi peserta didik dengan cara memberikan peringatan atau ancaman yang menekan. Cara ini cocok untuk kondidi yang susah dikendalikan.

9. Legitimizing Tactics, yaitu suatu cara mempengaruhi peserta didik dengan menggunakan otoritas dan kedudukannya. Penerapan cara ini lebih bersifat intruksional. ${ }^{16}$

${ }^{16}$ Ibid., h. 121-123 
Marah adalah bagian dari usaha mempengaruhi orang lain agar tidak melakukan sesuatu atau melakukan sesuatu. Marah dapat berdampak positif dan negatif pada peserta didik. Marah yang moderat akan menimbulkan dampak yang positif bagi peserta didik.

\section{Ḥadīs Tentang Marah Nabi Bentuk Marah Nabi}

1. Kemarahan Nabi saw kelihatan dari wajah yang menunjukan tidak suka terhadap sesuatu,sebagaimana yang diceritakan oleh Aisyah sebagai berikut,

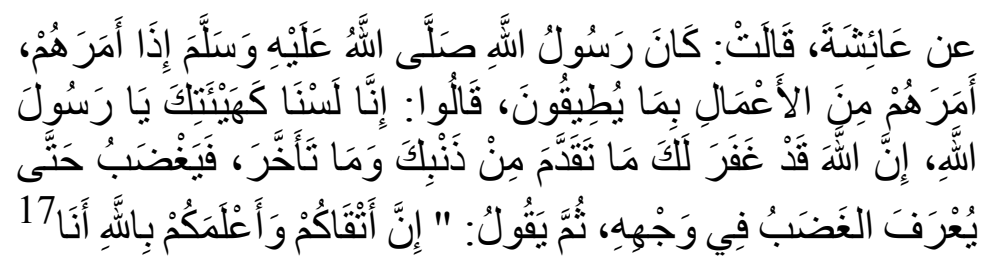

Kalimat yang menujukan kemarahan Nabi adalah

فَيَغْضَبُ حَنَّى يُعْرَفَ الغَضَبَبُ فِي وَجْهِهِ kemarahannya itu nampak diwajahnya).

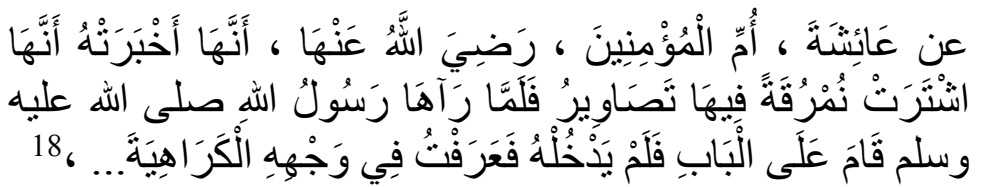

Dari Aisyah radliallahu 'anha bahwa dia telah membeli numruqah (bantal yang digunakan untuk duduk) yang ada gambarnya. Nabi shallallahu 'alaihi wasallampun berdiri di depan pintu dan tidak masuk ke dalam rumah, maka saya mengetahui ketidaksukaan di wajah Nabi.. "

2. Kemarahan Nabi nampak dari isi perkataan yang mematahkan argumentasi terhadap orang yang ngotot memepertahankan sikap beragama. Perkataan itu biasanya menegaskan ketinggian kedudukan Nabi, seperti aku lebih

${ }^{17}$ Muhammad bin Ismāil Abū Abdullah al-Bukhārī, Șaḥīh al-Bukhārī,Juz 1, (al-Maktabah al-Syāmilah, al-Maktabah al-Ta'āwun̄̄ wa al-Da'wah bi alRaudah, t.th.)., h. 13

${ }^{18}$ Muhammad bin Ismāil Abū Abdullah al-Bukhārī, Șah̄inh al-Bukhārī, Juz 3, (al-Maktabah al-Syāmilah, al-Maktabah al-Ta'āwunī wa al-Da'wah bi alRauḍah, t.th.)., h. 83. 
bertakwa dan lebih takut kepada Allah yang disertai dengan sumpah kepada Allah. Hal ini ditunjukan oleh bebarapa ḥadīis,

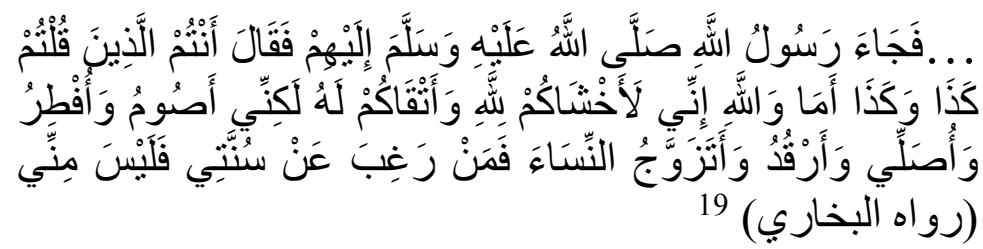

Dari Anas r.a. ia berkata: " ... Kemudian Rasul Allah datang dan bersabda kepada mereka, " Kalian tadi yang berbicara begini dan begitu?. Demi Allah, sesungguhnya aku adalah orang yang paling takut dan paling takwa kepada Allah diantara kalian, tetapi aku berpuasa dan berbuka, aku shalat dan aku tidur malam aku juga mengawini perempuan (itulah sunnah-sunnahku), siapa saja yang benci terhadap sunnahku, maka ia bukan termasuk golonganku. (H.R. al-Bukhari).

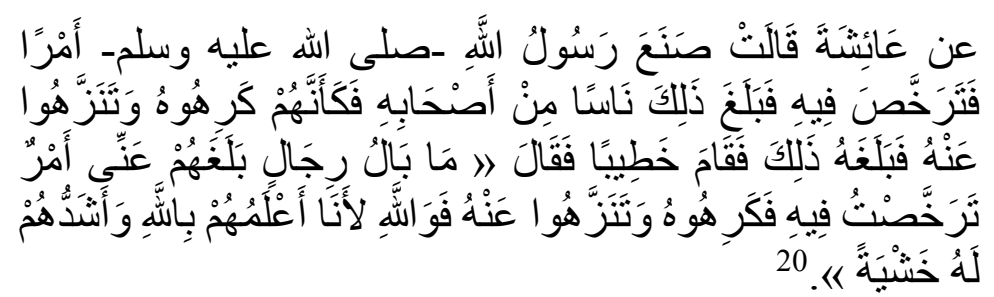

Dari 'Aisyah ia berkata: Rasulullah shallallahu 'alaihi wasallam memberikan suatu keringanan pada salah satu perintah beliau. Lalu hal itu sampai kepada sebagian sahabatnya dan mereka pun seperti kurang suka dan berlepas dari dari hal itu. maka sampailah kabar mengenai sikap mereka itu kepada Rasulullah shallallahu 'alaihi wasallam sehingga beliau pun berdiri dan berkhutbah: "Kenapa ada orang yang telah sampai kepada mereka suatu urusan dariku yang aku mendapatkan keringanan karenanya lalu mereka membencinya dan berlepas darinya?! Demi Allah, sungguh aku adalah orang yang lebih mengenal Allah daripada mereka dan aku adalah orang yang paling takut kepadaNya".

3. Kemarahan nampak dari isi perkataan Nabi yang menyayangkan sikap kebodohan, kemunduran dan

${ }^{19}$ Muhammad bin Ismāil Abū Abdullah al-Bukhārī, Șah̄in al-Bukhārī,Juz 15, (al-Maktabah al-Syāmilah, al-Maktabah al-Ta'āwunī wa al-Da'wah bi alRauḍah, t.th.)., h. 493.

${ }^{20}$ Muslim, Ṣah̄īh Muslim, Juz 7, (al-Maktabah al-Syāmilah, al-Maktabah al-Ta'āwunī wa al-Da'wah bi al-Rauḍah, t.th.)., h. 90. 
kekeliruan orang lain yang disertai dengan sumpah kepada Allah.

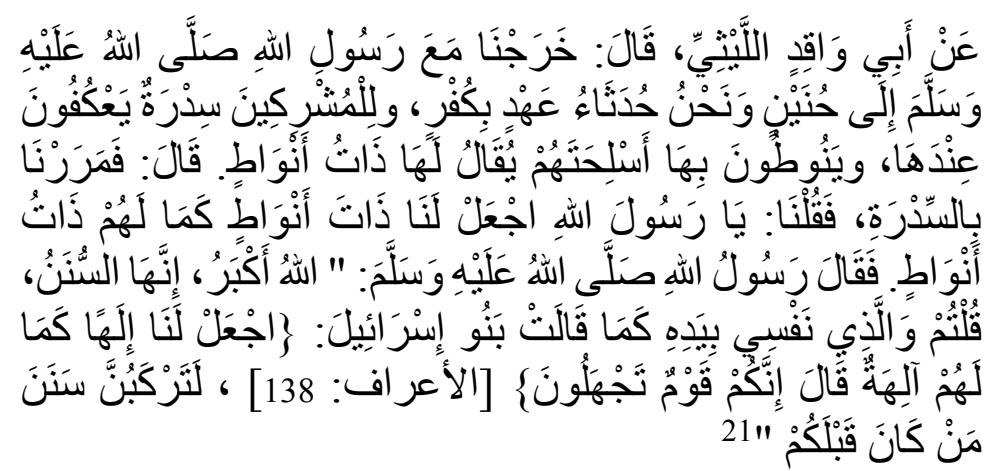

Dari Abu Waqid al-Laitsi, beliau berkata, “ Kami berangkat bersama Rasul Allah s.a.w. menuju Hunain sementara kami dalam keadaan baru terlepas dari kekufuran, dan orang-orang musyrikin mempunyai sebuah pohon bidara yang bernanma Dzatu Anwath, mereka senantiasa berkerumun di sekitarnya dan menggantungkan senjatasenjata mereka padanya. Kemudian kami melewati sebuah pohon Bidara lain, maka kami berkata, Ya Rasul Allah, buatkanlah Dzatu Anwath untuk kami,! Maka Rasul Allah s.a.w. bersabda, 'Allahu Akbar'. Ia adalah Tradisi-tradisi. Demi Dzat yang jiwaku berada di TanganNya, kalian telah berkata sebagaimana perkataan Bani Israil kepada Musa, 'Buatkanlah untuk kami sebuah tuhan (berhala)., Musa menjawab'Sesungguhnya kamu ini adalah kaum yang tidak mengetahi (sifat-sifat Tuhan)'.(al-A'raf: 138). Kalian pasti akan mengikuti tradisi orang-orang sebelum kalian.

4. Kemarahan Nabi nampak dari wajah yang memerah

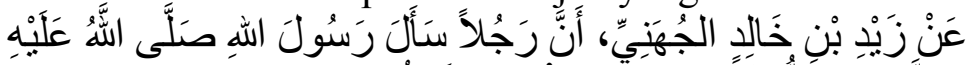

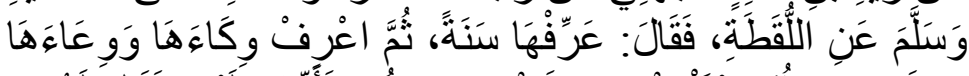

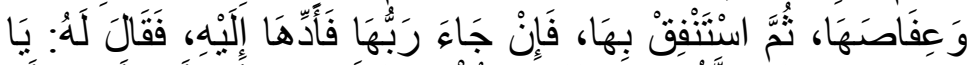

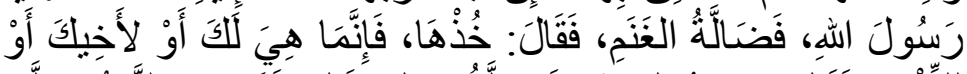

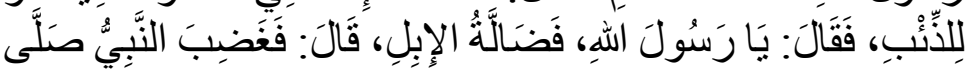

${ }^{21}$ Al-Ṭabrān̄i, al-Mu'jam al-Kabīr, (Kairo: Maktabah Ibnu Taimiyyah), Juz. 3, h. 244. 


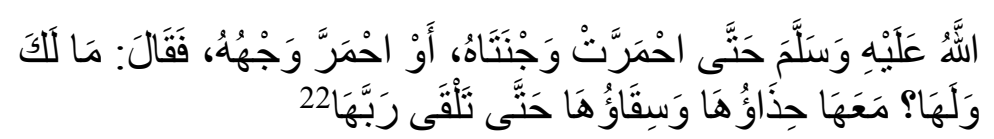

Dari Zaid bin Khalid al-Juhani, bahwa seorang laki-laki bertanya kepada Rasul Allah mengenai barang temuan, beliau berkata: "umumkan satu tahun, kemudian ketahuilah talinya dan kantongnya kemudian nafkahkan pada dirimu. Apabila pemiliknya datang maka berikan kepadanya." Lalu orang tersebut berkata; waha Rasul Allah, bagaimana dengan kambing yang tersesat? Beliau bersabda:"ambilah kambing tersebut, sesungguhnya kambing tersebut adalah milikmu atau saudaramu atau miliki srigala." Ia berkata; waha Rasul Allah bagaimana dengan unta yang tersesat? Kemudia Rasul Allah marah hingga kedua pipinya atau wajahnya memerah. Beliau berkata: apa urusanmu dengannya? Ia memiliki sepatu, dan kantong air minum hingga pemiliknya mendapatkannya

\section{Perkara-Perkara Yang Menyebabkan Nabi Marah}

Nabi saw marah bukan disebabkan oleh persoalan pribadi melainkan disebabkan larangan Allah dilanggar. Kemarahan Nabi pada hakikatnya adalah sebagai bentuk kasih sayang terhadap umatnya. Umatnya dijaga agar tidak melanggar larangan-larangan Allah, sehingga mereka tidak tertimpa kerugian.

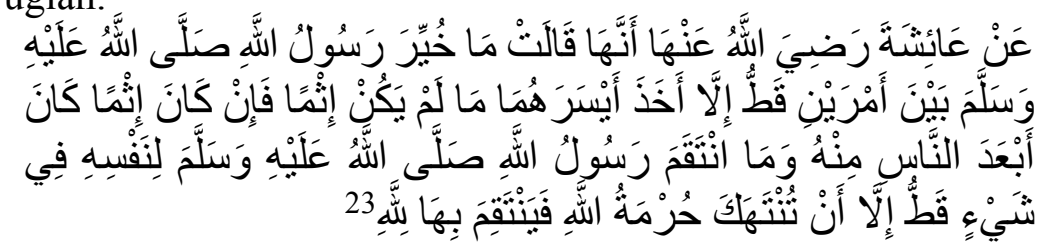

Dari Dari Aisyah radliallahu 'anha bahwa dia berkata; "Tidaklah Rasulullah shallallahu 'alaihi wasallam merasa bingung terhadap dua pilihan melainkan beliau akan memilih perkara yang lebih mudah (ringan) selama hal itu tidak mengandung dosa. Jika perkara itu mengandung dosa, maka beliau adalah orang yang paling menjauhkan diri dari padanya. Dan tidaklah Rasulullah shallallahu 'alaihi wasallam marah terhadap suatu perkara, melainkan bila beliau melihat larangan Allah dilanggar, maka beliau akan marah karena Allah."

Secara terinci, perkara-perkara yang membuat Nabi saw marah sebagaimana peristiwa-peristiwa dibawah ini;

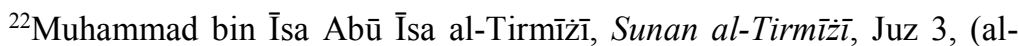
Maktabah al-Syāmilah, al-Maktabah al-Ta'āwunī wa al-Da'wah bi al-Rauḍah, t.th.)., h.48.

${ }^{23}$ Muhammad bin Ismāil Abū Abdullah al-Bukhārī, Șaḥ̄h al-Bukhārī,Juz 4, (al-Maktabah al-Syāmilah, al-Maktabah al-Ta'āwun̄̄ wa al-Da'wah bi alRaudiah, t.th.)., h. 230.
} 
1. Adanya sekelompok orang yangtetap bersikeras untuk melaksanakan beban agama (taklïf) menurut takaran dan pemahamannya sendiri bukan menurut takaran syariat yang telah ditentukan, sebagaimana dalam sebuah hadits berikut;

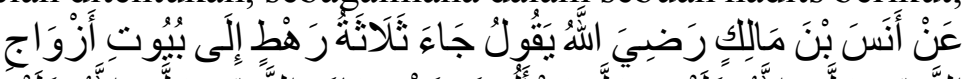

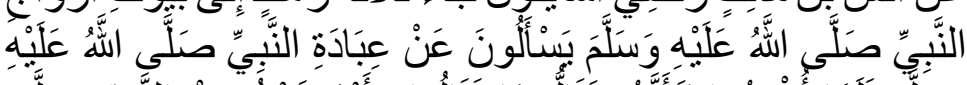

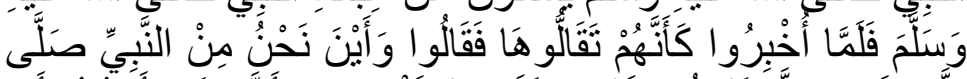

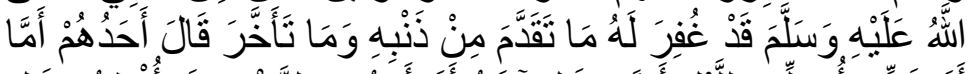

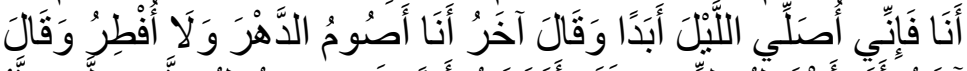

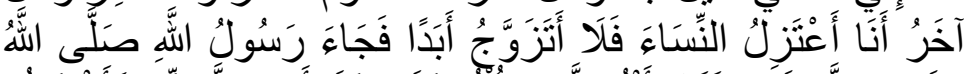

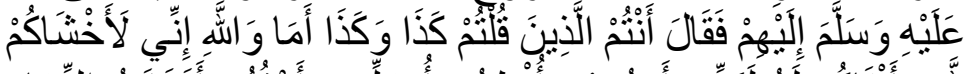

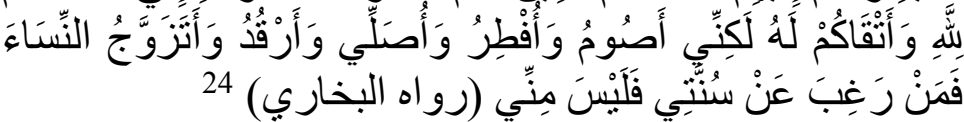

Dari Anas r.a. ia berkata: " Tiga orang datang ke isteri Nabi saw. mempertanyaan tentang ibadah Nabi saw. Setelah diberi tahu, mereka menganggap seakan-akan amal ibadah Nabi saw itu sedikit dan mereka berkata' dimanakah tempat kami dibanding Nabi saw, padahal beliau telah diampuni dosanya baik yang telah lalu maupun yang akan datang". Salah seorang diantara mereka berkata," Saya selamanya shalat sepanjang malam". Yang lain berkata," Saya selamanya berpuasa". Yang lain lagi berkata," Saya akan menjauhkan diri dari perempuan dan tidak akan kawin selama-lamanya". Kemudian Rasul Allah datang dan bersabda kepada mereka, " Kalian tadi yang berbicara begini dan begitu?. Demi Allah, sesungguhnya aku adalah orang yang paling takut dan paling takwa kepada Allah diantara kalian, tetapi aku berpuasa dan berbuka, aku shalat dan aku tidur malam aku juga mengawini perempuan (itulah sunnah-sunnahku), siapa saja yang benci terhadap sunnahku, maka ia bukan termasuk golonganku. (H.R. al-Bukhary).

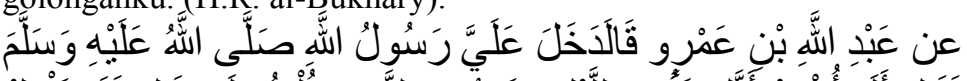

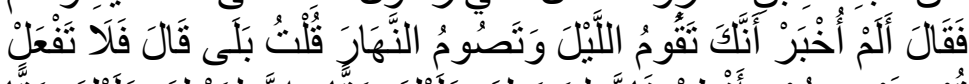

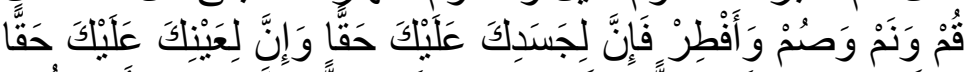

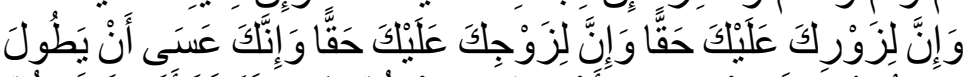

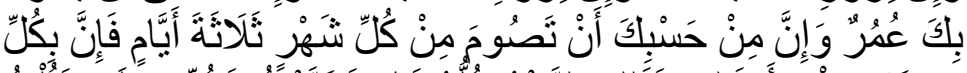

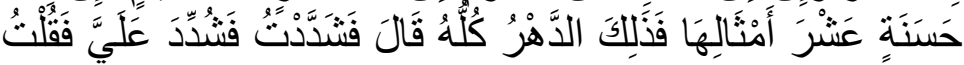

${ }^{24}$ Muhammad bin Ismāil Abū Abdullah al-Bukhārī, Șaḥ̄h al-Bukhārī,Juz 15, (al-Maktabah al-Syāmilah, al-Maktabah al-Ta'āwunī wa al-Da'wah bi alRauḍah, t.th.).,h. 493. 


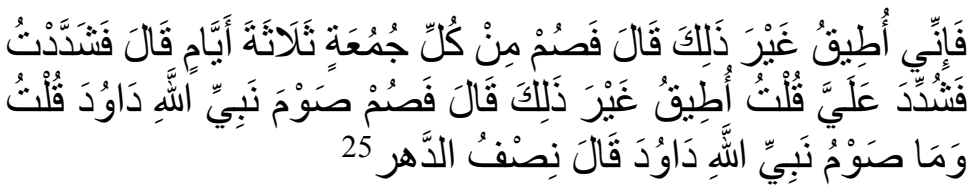

Abdullah bin 'Amru dia berkata; "Rasulullah shallallahu 'alaihi wasallam menemuiku, lalu beliau bersabda: "Aku memperoleh berita bahwa kamu bangun di malam hari dan berpuasa di siang hari, benarkah itu?" Aku menjawab; "Benar." Beliau bersabda: "Jangan kamu lakukannya; namun tidur dan bangunlah, berpuasa dan berbukalah. Karena tubuhmu memiliki hak atas dirimu, kedua matamu memiliki hak atas dirimu, tamumu memiliki hak atas dirimu, istrimu memiliki hak atas dirimu. Sungguh, semoga panjang umur dan cukup bagimu berpuasa tiga hari dalam setiap bulan, dan suatu kebaikan akan dibalas dengan sepuluh kali lipatnya, itulah puasa Dahr." Abdullah bin 'Amru berkata; "Aku bersikap keras dan beliau pun bersikap keras kepadaku, lalu kataku; "Sungguh aku masih kuat melakukan lebih dari itu?". Beliau bersabda: "Berpuasalah tiga hari setiap Jum'at." Abdullah bin 'Amru berkata; "Aku bersikap keras dan beliau pun bersikap keras kepadaku, lalu kataku; "Sungguh aku masih kuat melakukan lebih dari itu?" Beliau bersabda: "Kalau begitu, berpuasalah seperti puasanya Nabiyullah Daud." Aku bertanya; "Bagaimana puasa Nabiyullah Daud?" Beliau bersabda: "Yaitu puasa setengah zaman (sehari puasa sehari berbuka).“

Penyebab kemarahan Nabi dalam ḥadīs di atas adalah sikap tiga orang yang akan melakukan ibadah secara berlebihan melampau batas-batas ketentuan Nabi. Ibadah yang demikian tentu akan menghancurkan diri sendiri karena melampaui batas takaran.

Ada dua pernyataan yang menunjukan bahwa Nabi marah, Pertama, Pernyataan Nabi," Demi Allah , sesungguhnya aku adalah orang yang paling takut dan paling takwa kepada Allah diantara kalian, tetapi aku berpuasa dan berbuka, aku shalat dan aku tidur malam aku juga mengawini perempuan (itulah sunnah-sunnahku)". Kedua, pernyataan Nabi, " siapa saja yang benci terhadap sunnahku, maka ia bukan termasuk golonganku".

Kemarahan Nabi juga nampak pada wajah beliau sebagaimana yang diceritakan Aisyah sebagai berikut,

${ }^{25}$ Muhammad Muhammad bin Ismāil Abū Abdullah al-Bukhārī, Șậinh alBukhārī,al-Juz 8, (al-Maktabah al-Syāmilah, al-Maktabah al-Ta'āwunī wa alDa'wah bi al-Rauḍah, t.th.)., h. 31 


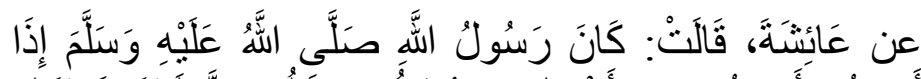

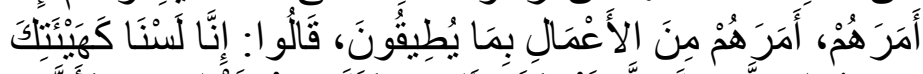

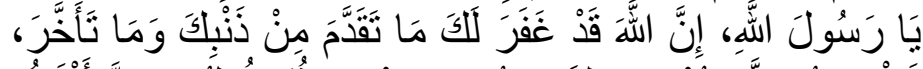

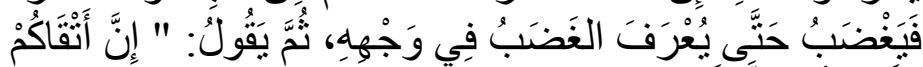

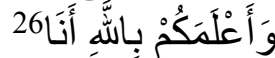

Kalimat yang menujukan kemarahan Nabi adalah

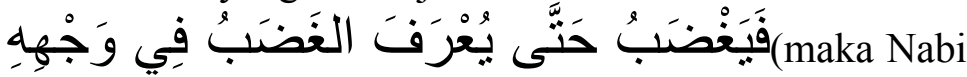
marah dan kemarahannya itu nampak diwajahnya)

2. Adanya sekelompok orang yang mengusulkan pada Nabi saw untuk diadakan ritual sebagaimana dilakukan oleh kaum musyrikin yang sebenarnya justru menunjukan langkah mundur

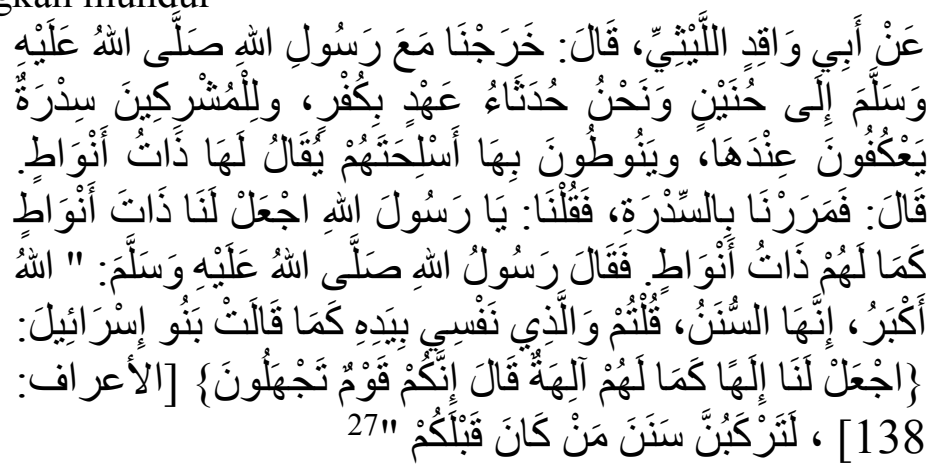

Dari Abu Waqid al-Laitsi, beliau berkata, "Kami berangkat bersama Rasul Allah s.a.w. menuju Hunain sementara kami dalam keadaan baru terlepas dari kekufuran, dan orang-orang musyrikin mempunyai sebuah pohon bidara yang bernanma Dzatu Anwath, mereka senantiasa berkerumun di sekitarnya dan menggantungkan senjatasenjata mereka padanya. Kemudian kami melewati sebuah pohon Bidara lain, maka kami berkata, Ya Rasul Allah, buatkanlah Dzatu Anwath untuk kami,! Maka Rasul Allah s.a.w. bersabda, ' Allahu Akbar'. Ia adalah Tradisi-tradisi. Demi Dzat yang jiwaku berada di TanganNya, kalian telah berkata sebagaimana perkataan Bani Israil kepada Musa, 'Buatkanlah untuk kami sebuah tuhan (berhala)., Musa menjawab'Sesungguhnya kamu ini adalah kaum yang tidak

${ }^{26}$ Muhammad Muhammad bin Ismāil Abū Abdullah al-Bukhārī, Șaḥīh alBukhārī,al-Juz 1, (al-Maktabah al-Syāmilah, al-Maktabah al-Ta'āwun̄̄ wa alDa’wah bi al-Rauḍah, t.th.).,h. 13.

${ }^{27}$ Al-Ṭabrānī, al-Mu'jam al-Kabīr,Juz 3., (Kairo, Maktabah Ibnu Taimiyyah)., h.244. 
mengetahi (sifat-sifat Tuhan)'.(al-A'raf: 138). Kalian pasti akan mengikuti tradisi orang-orang sebelum kalian

3. Adanya seseorang yang memperberat ibadah fardhu bagi orang lain

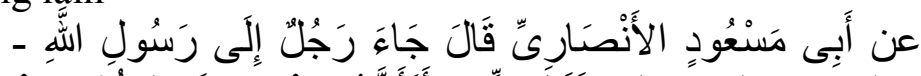

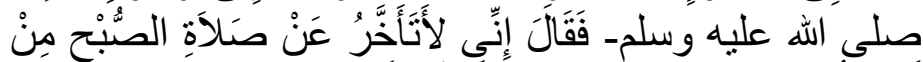

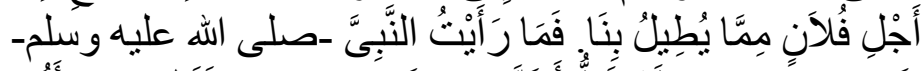

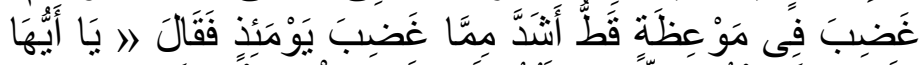

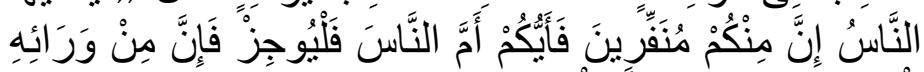

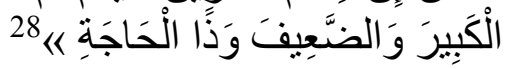

Dari Abu Mas'ud radliallahu 'anhu dia berkata; "Seorang laki-laki datang kepada Nabi shallallahu 'alaihi wasallam sambil berkata; "Sesungguhnya aku akan mengakhirkan shalat shubuh karena fulan yang memanjangkan (bacaannya)." Abu Mas'ud berkata; "Maka aku tidak pernah melihat Rasulullah shallallahu 'alaihi wasallam sangat marah dalam menyampaikan nasihatnya melebihi marahnya beliau pada hari itu, Abu Mas'ud melanjutkan; "Lalu beliau bersbada: "Wahai sekalian manusia, sesungguhnya di antara kalian ada yang menjadikan orang-orang lari (dari keta'atan), barangsiapa di antara kalian shalat dengan orang banyak, hendaklah ia memperingan shalatnya, sebab di antara mereka ada orang yang lemah, orang yang sudah lanjut usia dan orang yang mempunyai keperluan"

\section{Adanya seseorang yang menolak Dispensasi Nabi}

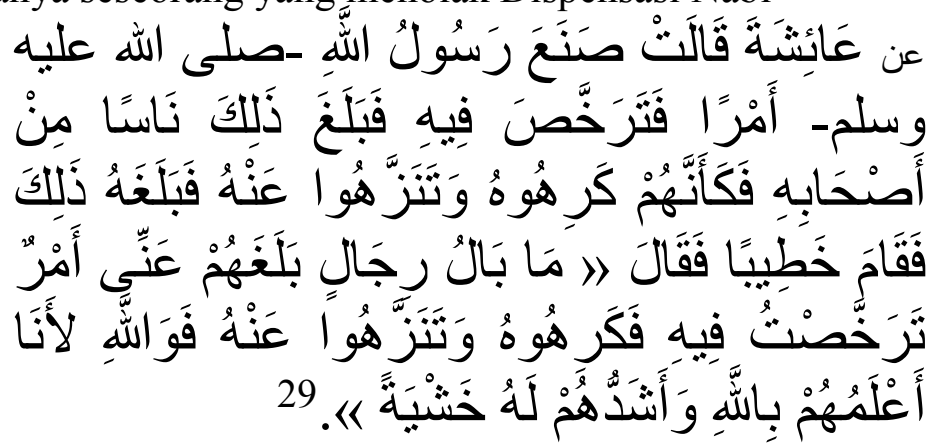

Dari 'Aisyah ia berkata: Rasulullah shallallahu 'alaihi wasallam memberikan suatu keringanan pada salah satu perintah beliau. Lalu hal itu sampai kepada sebagian sahabatnya dan mereka pun seperti kurang suka dan berlepas dari dari hal itu. maka sampailah kabar mengenai sikap mereka itu kepada Rasulullah shallallahu 'alaihi wasallam sehingga beliau pun berdiri dan berkhutbah:

${ }^{28}$ Muslim, Saḥ̄hh Muslim.,(al-Maktabah al-Syāmilah, al-Maktabah alTa'āwunī wa al-Da'wah bi al-Rauḍah, t.th.)., h. 42.

${ }^{29}$ Muslim, Sậ̄in Muslim, h. 90. 
"Kenapa ada orang yang telah sampai kepada mereka suatu urusan dariku yang aku mendapatkan keringanan karenanya lalu mereka membencinya dan berlepas darinya?! Demi Allah, sungguh aku adalah orang yang lebih mengenal Allah daripada mereka dan aku adalah orang yang paling takut kepadaNya".

5. Adanya seseorang yang menganggap kecil nilai suatu ibadah

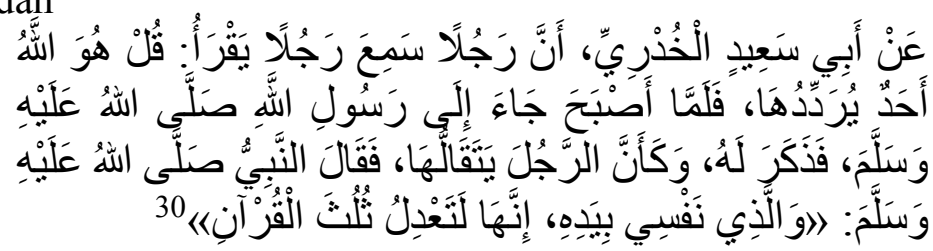

Dari Abu Sa'id (Al Khuḍī) bahwa seorang laki-laki mendengar seseorang membaca dengan berulang-ulang 'Qul huwallahu ahad'. Tatkala pagi hari, orang yang mendengar tadi mendatangi Rasulullah shallallahu 'alaihi wa sallam dan menceritakan kejadian tersebut dengan nada seakan-akan merendahkan surat al Ikhlas. Kemudian Rasulullah shallallahu 'alaihi wa sallam bersabda, "Demi yang jiwaku berada di tangan-Nya, sesungguhnya surat ini sebanding dengan sepertiga Al Qur'an".

6. Adanya seseorang yang kurang menghormati Syiar-syiar Allah

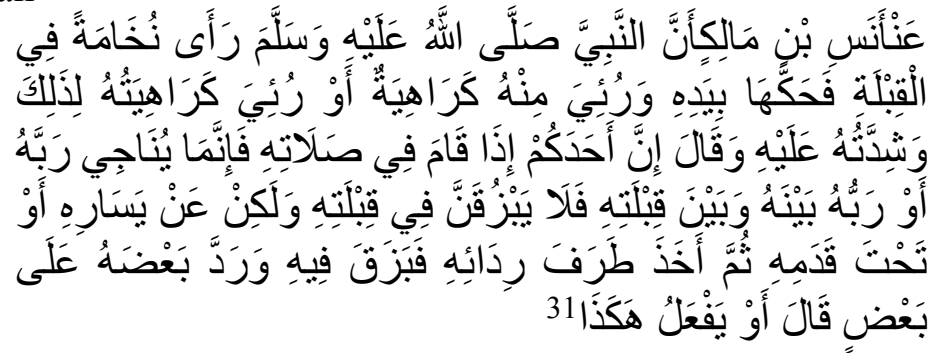

Dari Anas bin Malik, bahwa Nabi shallallahu 'alaihi wasallam melihat dahak di dinding kiblat lalu menggosoknya dengan tangannya. Dan nampak kebencian dari beliau, atau kebenciannya terlihat karena hal itu. Beliau pun bersabda: "Jika salah seorang dari kalian berdiri shalat, sesungguhnya ia sedang berhadapan dengan Rabbnya, atau sesungguhnya Rabbnya berada antara dia dan arah kiblatnya, maka janganlah ia meludah ke arah kiblat. Tetapi hendaklah ia lakukan ke arah kiri atau di bawah kaki (kirinya)." Kemudian Nabi shallallahu 'alaihi wasallam

${ }^{30}$ Abū Daud, Sunan Abū Daud, Juz 2, (al-Maktabah al-Syāmilah, alMaktabah al-Ta'āwun̄̄ wa al-Da'wah bi al-Rauḍah, t.th.)., h. 72.

${ }^{31}$ Muhammad Muhammad bin Ismāil Abū Abdullah al-Bukhārī, Ṣah̄inh alBukhārī., h.113. 
memegang tepi kainnya dan meludah di dalamnya, setelah itu beliau membalik posisi kainnya lalu berkata, atau beliau melakukan seperti ini."

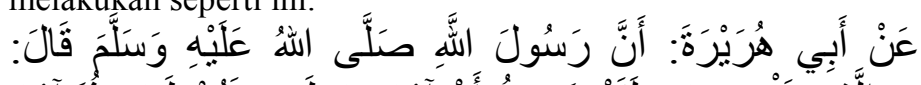

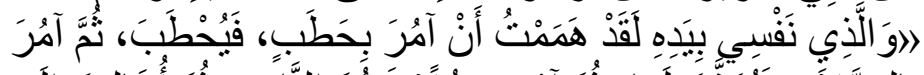

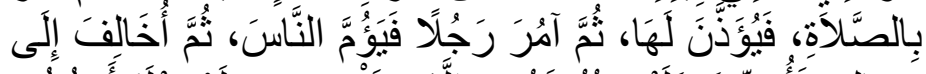

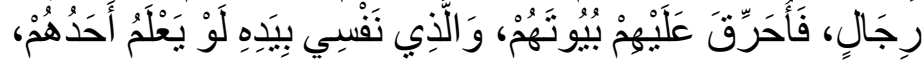

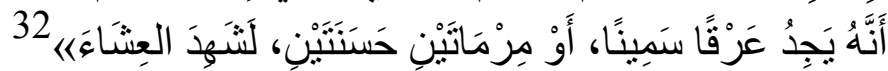

Dari Abi Hurairah sesungguhnya Rasulullah saw bersabda, "Demi Dzat yang mana jiwaku berada di tangan-Nya, sesungguhnya aku sangat ingin memerintahkan (orang-orang) untuk mengumpulkan kayu bakar lalu dinyalakan, kemudian aku memerintahkan shalat sehingga dikumandangkanlah adzan untuk itu, lalu aku memerintahkan seseorang laki-laki untuk mengimami mereka, sementara aku mencari orang-orang (yang tidak mengikuti shalat berjama'ah) dan aku bakar rumah mereka. Demi Dzat yang mana jiwaku berada di tangan-Nya, seandainya seseorang di antara mereka mengetahui bahwa ia akan mendapatkan potongan daging yang gemuk atau dua binatang buruan yang baik, niscaya ia akan mengikuti jama'ah shalat Isya

7. Adanya seseorang yang memepermainkan hukum Allah

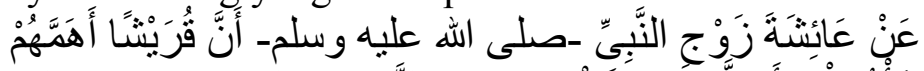

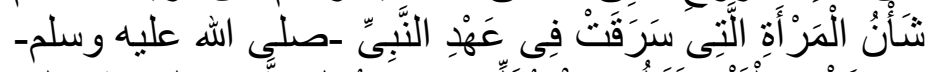

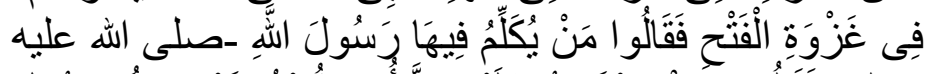

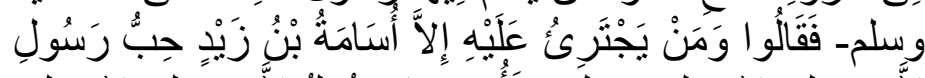

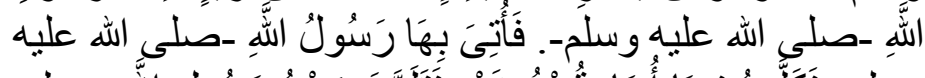

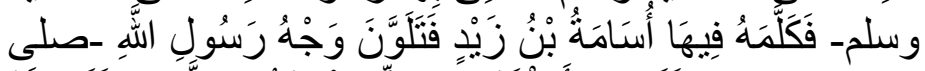

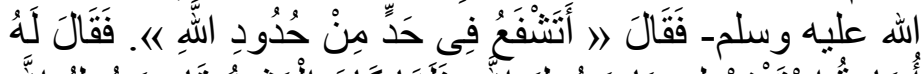

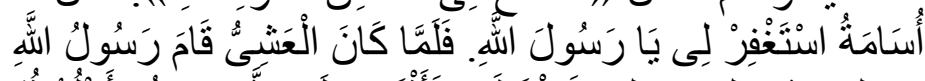

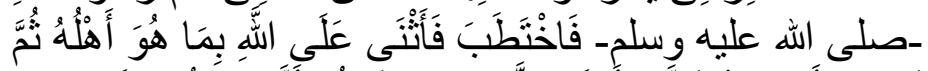

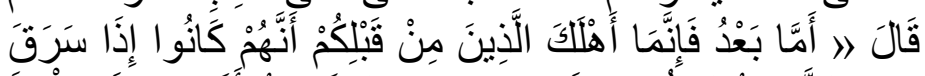

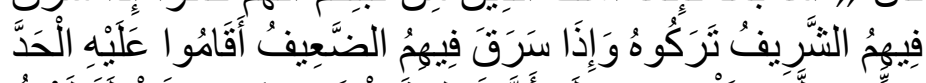

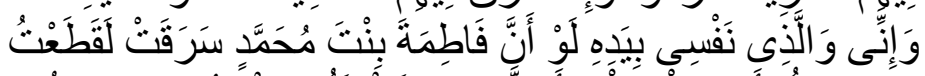

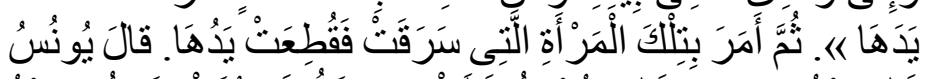

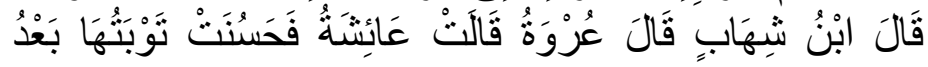

${ }^{32}$ Ibid., h. 131. 


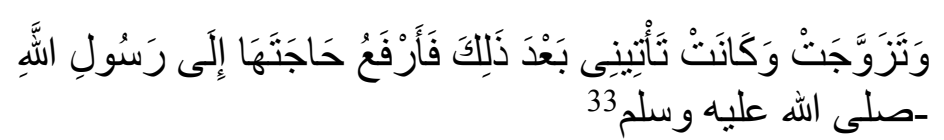

Dari 'Aisyah isteri Nabi shallallahu 'alaihi wasallam, bahwa saat penaklukan Kota Makkah di masa Rasulullah shallallahu 'alaihi wasallam, orang-orang Quraisy pernah kebingungan mengenai masalahnya seorang wanita (mereka) yang ketahuan mencuri. Maka mereka berkata, "Siapa kiranya yang berani mengadukan permasalahan ini kepada Rasulullah shallallahu 'alaihi wasallam?" maka sebagian mereka mengusulkan, "Siapa lagi kalau bukan Usamah bin Zaid, orang yang paling dicintai oleh Rasulullah shallallahu 'alaihi wasallam." Lalu wanita itu dihadapkan kepada Rasulullah shallallahu 'alaihi wasallam dan Usamah bin Zaid pun mengadukan permasalahannya kepada beliau, tiba-tiba wajah Rasulullah shallallahu 'alaihi wasallam berubah menjadi merah seraya bersabda: "Apakah kamu hendak meminta syafa'at (keringanan) dalam hukum Allah (yang telah ditetapkan)!" Maka Usamah berkata kepada beliau, "Mohonkanlah ampuanan bagiku wahai Rasulullah." Sore harinya Rasulullah shallallahu 'alaihi wasallam berdiri dan berkhutbah, setelah memuji Allah dengan ujian yang layak untuk-Nya, beliau bersabda: "Amma Ba'du. Sesungguhnya yang membinasakan orang-orang sebelum kalian adalah manakala ada orang yang terpandang (terhormat) dari mereka mencuri, maka merekapun membiarkannya. Namun jika ada orang yang lemah dan hina di antara mereka ketahuan mencuri, maka dengan segera mereka melaksanakan hukuman atasnya. Demi Dzat yang jiwaku berada tangan-Nya, sekiranya Fatimah binti Muhammad mencuri, sungguh aku sendiri yang akan memotong tangannya." Akhirnya beliau memerintahkan terhadap wanita yang mencuri, lalu dipotonglah tangan wanita tersebut." Yunus berkata; Ibnu Syihab berkata; Urwah berkata; 'Aisyah berkata, "Setelah peristiwa itu, wanita tersebut malakukan taubat nasuha dan menikah, hingga pada suatu ketika ia datang kepadaku untuk meminta tolong mengajukan permintaannya kepada Rasulullah shallallahu 'alaihi wasallam, lalu aku memenuhi permintaannya tersebut." Dan telah menceritakan kepada kami 'Abd bin Humaid telah mengabarkan kepada kami Abdurrazaq telah mengabarkan kepada kami Ma'mar dari Az Zuhri dari 'Urwah dari 'Aisyah dia berkata, "Seorang wanita Makhzumiyah pernah meminjam suatu barang, setelah itu dia mengaku barang tersebut adalah miliknya. Maka Nabi shallallahu 'alaihi wasallam menyuruh supaya tangannya dipotong, hingga keluarga wanita tersebut menemui Usamah bin Zaid dan mengadukan permasalahan wanita itu. Usamah lalu mengadukannya kepada Rasulullah shallallahu 'alaihi

\footnotetext{
${ }^{33}$ Muslim, Șạ̄ih Muslim., h.114.
} 
wasallam ...', kemudian dia menyebutkan seperti hadits Laits dan Yunus."

Kemarahan Nabi saw nampak dari memerahnya wajah Nabi saw yang disebabkan hukum Allah dipermainkan. Nabi tidak ingin kehancuran menimpa sahabatnya, seraya berkata, "Sesungguhnya yang membinasakan orang-orang sebelum kalian adalah manakala ada orang yang terpandang (terhormat) dari mereka mencuri, maka merekapun membiarkannya. Namun jika ada orang yang lemah dan hina di antara mereka ketahuan mencuri, maka dengan segera mereka melaksanakan hukuman atasnya".

8. Adanya gambar makhluk hidup di dalam rumah

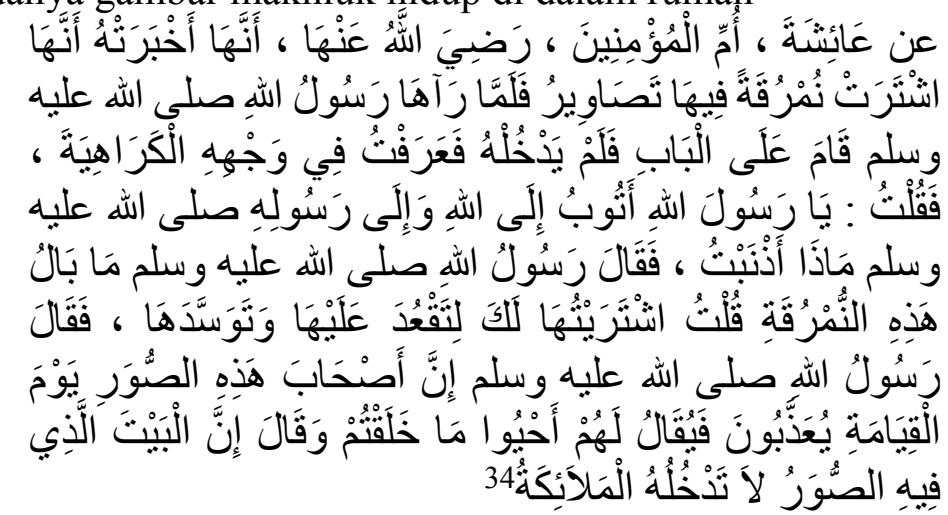

Dari Aisyah radliallahu 'anha bahwa dia telah membeli numruqah (bantal yang digunakan untuk duduk) yang ada gambarnya. Nabi shallallahu 'alaihi wasallampun berdiri di depan pintu dan tidak masuk ke dalam rumah. maka saya bertanya; "Wahai Rasulullah, aku bertaubat kepada Allah, sebenarnya dosa apa yang telah aku perbuat?" beliau bersabda: "Bantal apakah ini?" Dia menjawab; "Aku telah membelinya agar anda duduk di atasnya atau anda jadikan sebagai bantal." Beliau bersabda: "Sesungguhnya orang yang menggambar gambar ini akan disiksa pada Hari Kiamat. Dikatakan kepada mereka; 'Hidupkan yang telah kalian buat, ' (beliau bersabda): "Sesungguhnya malaikat tidak akan masuk ke dalam rumah yang ada gambarnya."

Kemarahan Nabi nampak dari sikap Nabi yang tidak mau masuk ke dalam rumah yang di dalamnya ada bantal bergambar dan nampak dari wajah Nabi.

${ }^{34}$ Muhammad Muhammad bin Ismāil Abū Abdullah al-Bukhārī, Șaḥ̄h alBukhārī,Juz 3, (al-Maktabah al-Syāmilah, al-Maktabah al-Ta'āwunī wa alDa'wah bi al-Rauḍah, t.th.).,h. 83 . 
Nabi memberikan dua alasan. Pertama, orang yang menggambar akan disiksa pada hari kiamat. Kedua, malaikat tidak akan masuk ke dalam rumah yang ada gambarnya.

9. Adanya seorang laki-laki yang menyerupai Perempuan

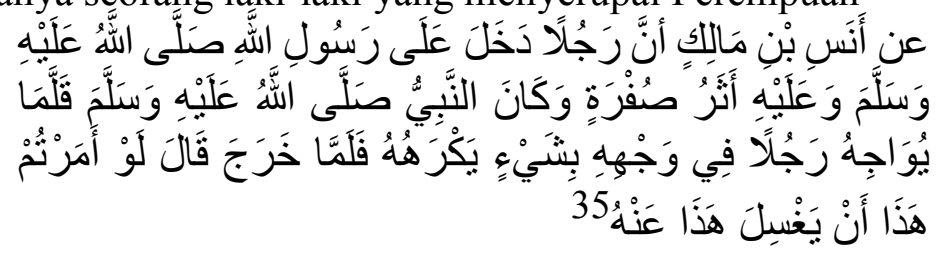

DariAnas bin Malik berkata, "Seorang laki-laki masuk menemui Rasulullah shallallahu 'alaihi wasallam, sementara pada dirinya terdapat sisa-sisa warna kuning (Za'faran). Dan jarang sekali Nabi shallallahu 'alaihi wasallam menemui seseorang dengan wajah yang kurang senang karena sesuatu, maka ketika keluar beliau bersabda: "Sekiranya kalian suruh orang ini untuk membersihkan dirinya dari sisa-sisa warna kuning."

Hadis di atas menunjukan ketidaksenangan Nabi ketika ada seseorang yang tidak membersihkan bekas kuning yang ada diwajahnya, padahal Nabi tidak pernah bersikap seperti itu. Nabi tidak menyukai hal itu karena malaikat tidak mau hadir pada orang yang melakukan hal itu, karena perbuatan itu menyerupai wanita. Islam melarang seorang laki-laki yang menyerupai wanita termasuk memakai za'farān. Hal ini dikuatkan dengan ḥadis,

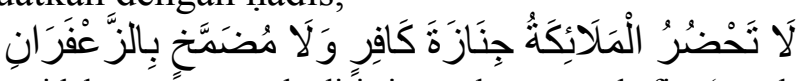

Malaikat tidak mau menghadiri janazah orang kafir (untuk memberi kesaksian dengan kebaikan) dan orang yang melumuri badannya dengan minyak za'farān (yang khusus bagi wanita

10. Adanya seorang laki-laki yang memakai cincin dari emas

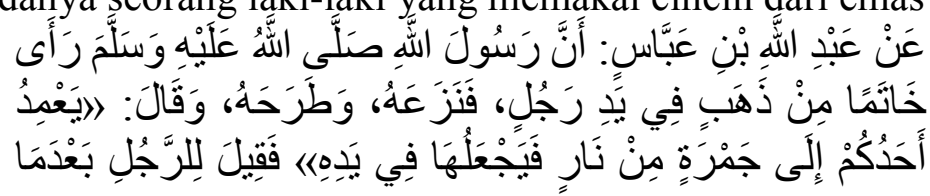

${ }^{35}$ Abū Daud, Sunan Abū Daud,(Ensiklopedi Hadits Kitab 9 Imam, LKFR2MZ3)., h. 3650. 


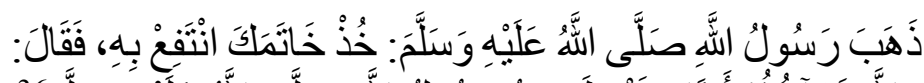

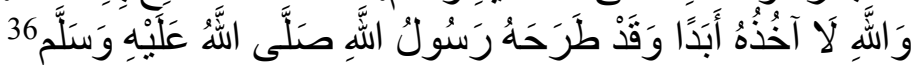

Dari Abd Allah ibn Abbas, dia berkata: Sesungguhnya Rasul Allah saw melihat cincin emas di tangan seseorang, kemudian Nabi melepas dan membuangnya dan bersabda, "Salah seorang di antara kalian sengaja mengambil bara api dan menaruhnya di tangannya". Setelah Rasul Allah saw berlalu, ada seseorang berkata kepada orang yang memakai cincin itu, "ambilah cincinmu dan manfaatkanlah". Jawabnya, "tidak, demi Allah saya tidak akan mengambil cincin itu selamanya, karena Rasul Allah saw telah membuangnya".

Kemarahan Nabi saw nampak ketika beliau melepas dan membuang cincin emas dari seorang lakilaki. Dan hal ini menunjukkan kasih sayang Nabi pada laki-laki tersebut, karena Nabi tidak ingin bara api membakar tangan laki-laki tersebut, sebagaimana penjelasan Nabi saw "Salah seorang di antara kalian sengaja mengambil bara api dan menaruhnya di tangannya".

11. Adanya seseorang menanyakan sesuatu yang tidak perlu

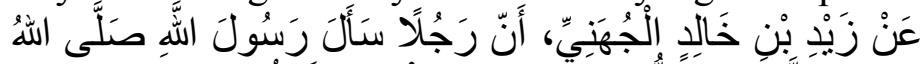

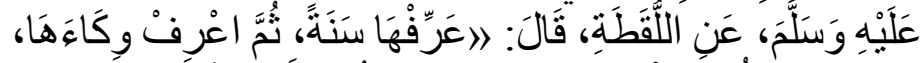

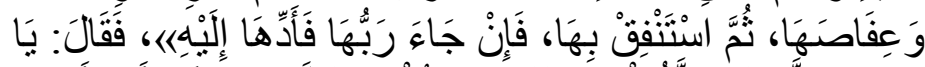

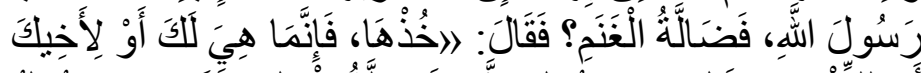

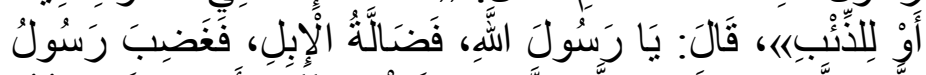

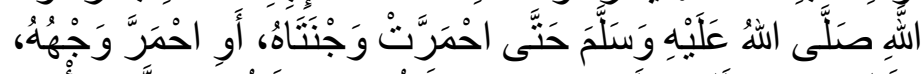

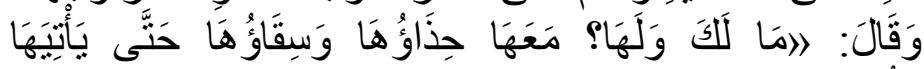
رَبُّهَانان.

Dari Zaid bin Khalid al-Juhani, bahwa seorang laki-laki bertanya kepada Rasul Allah mengenai barang temuan, beliau berkata: "umumkan satu tahun, kemudian ketahuilah talinya dan kantongnya kemudian nafkahkan pada dirimu. Apabila pemiliknya datang maka berikan kepadanya." Lalu orang tersebut berkata; waha Rasul Allah, bagaimana dengan kambing yang tersesat? Beliau bersabda:"ambilah kambing tersebut, sesungguhnya kambing tersebut adalah milikmu atau saudaramu atau miliki srigala." Ia berkata; waha Rasul Allah bagaimana

${ }^{36}$ Al-Baihaqi, al-Adab li al-Baihaqi, Juz 1, (al-Maktabah al-Syāmilah, alMaktabah al-Ta'āwun̄̄ wa al-Da'wah bi al-Rauḍah, t.th.).,h. 218.

37 Abu Dawud, Sunan Abu Dawud, Juz 2, Bairut, al-Maktabah alAshriyyah, t.th. h. 135. 
dengan unta yang tersesat? Kemudia Rasul Allah marah hingga kedua pipinya atau wajahnya memerah. Beliau berkata: apa urusanmu dengannya? Ia memiliki sepatu, dan kantong air minum hingga pemiliknya mendapatkannya

Hadits yang semakna dengan ini juga diriwayatkan oleh al-Bukhari, Muslim, al-Tirmidzi dan Malik. Menurut al-Bani, kedudukan hadits ini adalah shahih. $^{38}$

\section{Implikasi Marah Dalam Pendidikan Islam}

Dalam komunikasi pendidikan terdapat pressur tactic, yaitu suatu motode dalam mempengaruhi peserta didik dengan cara memberikan peringatan atau ancaman yang menekan. Cara ini cocok untuk kondidi yang susah dikendalikan. Marah merupakan salah satu bentuk komunikasi untuk mempengaruhi peserta didik yang susah dikendalikan. Marah juga termasuk usaha untuk memperkuat atau memperlemah perilaku. Agar senantiasa lebih kuat dalam melaksanakan perintah Allah, peserta didik terkadang perlu dikuatkan dengan marah. Demikian juga agar senantiasa menjauhi perbuatan yang dapat mendatangkan murka, peserta didik perlu dilemahkan kehendaknya dengan marah. Hal ini yang sebenarnya disebut dengan reinforcmen. Reinforcment sendiri merupakan penggunaan konsekuensi untuk memperkuat perilaku. Dan menurut teori pendidikan Behavioristik, tingkah laku manusia dikendalikan oleh reward dan reinforcment dari lingkungan sekitar. ${ }^{39}$

Meskipun marah menjadi salah satu teknik untuk mempengaruhi perilaku peserta didik, marah tetap proporsional yang sesuai dengan apa yang diajarkan oleh Nabi. Berdasarkan kajian hadis di atas maka dapat disimpulkan bahwa marah yang proporsional adalah sebagai berikut;

1. Marah yang tidak menyakiti diri sendiri maupun perasaan dan fisik peserta didik seperti merusak barang, mencaci, mencela

${ }^{38}$ Abū Daud, Sunan Abū Daud, Ensiklopedi Hadits Kitab 9 Imam, LKFR2MZ3

${ }^{39}$ Chairul Anwar, Teori-Teori Pendidikan Klasik Hingga Kontemporer Formula dan Penerapannya dalam Pembelajaran, Yogyakarta: IRCiSod, 2017, h. 17. 
dan memukul, sebagaimana apa yang pernah digambarkan oleh Aisyah tentang akhlak Nabi saw,

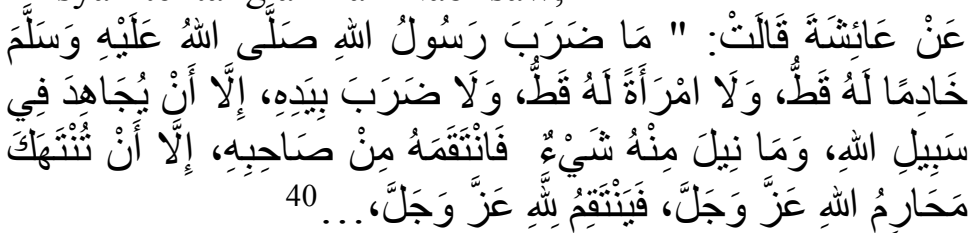

Dari Aisyah ra, Dia berkata, " Rasul Allah saw tidak pernah sama sekali memukul pembantunya, istrinya, beliau tidak pernah memukul dengan tangannya kecuali dalam jihad fi sabilillah. Dan tidaklah beliau disakiti lalu membalas pelakunya sama sekali kecuali jika dilanggar sedikit saja larangan Allah, maka beliau pun akan membalas pelakunya karena Allah..."

2. Marah sebagai bentuk ketidak setujuan atas sikap maupun tindakan yang dapat merugikan diri sendiri atau orang lain.

3. Marah bukan karena urusan duniawi, tapi karena urusan agama

4. Marah sebagai bentuk taktik untuk mempengaruhi orang lain dalam kondisi yang susah untuk dikendalikan

5. Marah penuh kasih sayang yakni marah yang didasari kesayangan pada peserta didik agar terselamatkan diri dari kerusakan di dunia dan di akhirat, sebagaimana Nabi saw senantiasa menjaga umatnya dari api neraka.

6. Marah edukatif yakni marah yang semata-mata untuk tujuan mendidik ke arah perbaikan

7. Marah bukan karena didorong oleh persoalan pribadi pendidik seperti didhalimi oleh peserta didik meskipun Islam memperbolehkan melakukan pembalasan yang setimpal. Namun Islam lebih mengapresiasi sikap memaafkan.

8. Marah yang disertai dengan penjelasan, mengapa seseorang harus melakukan atau meninggalkan sesuatu.

\section{Penutup}

Kasih sayang dapat diexpresikan melalui marah. Marah yang bermakna menunjukan pentingnya sesuatu yang harus dilakukan atau ditinggalkan. Marah diperbolehkan dalam hal-hal yang bersifat mendidik, diantaranya dalam bentuk- bentuk implikasi marah yang diperbolehkan dalam proses pendidikan dalam

\footnotetext{
${ }^{40}$ Ahmad Ibn Hanbal, Musnad Ahmad ibn Hanbal, juz 40, (al-Maktabah al-Syāmilah, al-Maktabah al-Ta'āwunī wa al-Da'wah bi al-Rauḍah, t.th.).,h. 37.
} 
perspektif hadits adalah (1). marah yang tidak menyakiti perasaan ataupun fisik peserta didik (2). Marah sebagai bentuk taktik untuk untuk mendidik dalam kondisi siswa yang susah dikendalikan, (3). Marah bertujuan menyelamatkan dari azab di dunia dan akhirat, (4). Marah yang tidak bertujuan untuk membalas dendam karena persoalan pribadi. Marah dilakukan agar orang-orang yang disayangi tidak terjerumus ke dalam kehanncuran, kegagalan atau kemurkaan Allah swt.

\section{Daftar Pustaka}

al-Baihaqi, t.th., al-Adab li al-Baihaqi, Juz 1, al-Maktabah alSyāmilah, al-Maktabah al-Ta'āwun̄̄ wa al-Da'wah bi alRauḍah.

al-Bukhārī, t.th, Muḥammad bin Ismāīl Abū Abdullah, Șahīh alBukhārī,Juz 1, al-Maktabah al-Syāmilah, al-Maktabah alTa'āwunī wa al-Da'wah bi al-Rauḍah,

al-Gazālī, AbūHāmid, Ihyya Ulūm al-Dīn, Bairūt, Dār al-Ma'ārif

al-Jabbār, Sayid Ibrāhīm, al-Taujih al-Falsafi wa al-Ijtimā'i li alTarbiyah, Maktabah Garīb

al-Ṣagīr, Fāliḥ bin Muḥammad bin Fāliḥ, t.th, Lā tagḍab Dirāsah

Hadisisyyah Da'awiyyah Nafsiyyah, al-Maktabah alSyāmilah, al-Maktabah al-Ta'āwun̄̄ wa al-Da'wah bi alRaudah

Al-Ṭabrānī, al-Mu'jam al-Kabīr, Juz 3., Kairo: Maktabah Ibnu Taimiyyah.

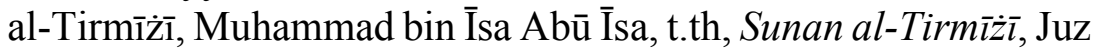
3, al-Maktabah al-Syāmilah, al-Maktabah al-Ta'āwun̄̄ wa alDa'wah bi al-Raudah.

Anwar, Chairul, 2017, Teori-Teori Pendidikan Klasik Hingga Kontemporer Formula dan Penerapannya dalam Pembelajaran, Yogyakarta: IRCiSod,.

Ațiyah bin Muhammad Sālim, t.th. Syarah al-Arba'̄n alNawawiyyah, Juz 40., al-Maktabah al-Syāmilah, alMaktabah al-Ta'āwunī wa al-Da'wah bi al-Raựah. 
Daud, Abū, Sunan Abū Daud, Ensiklopedi Hadits Kitab 9 Imam, LKFR2MZ3

Daud, Abū, t.th., Sunan Abū Daud, Juz 2, al-Maktabah alSyāmilah, al-Maktabah al-Ta'āwun̄̄ wa al-Da'wah bi alRaudah.

Hanbal, Ahmad Ibn, Musnad Ahmad ibn Hanbal (al-Maktabah alSyāmilah, al-Maktabah al-Ta'āwun̄̄ wa al-Da'wah bi alRauḍah, t.th.)

http://artikata.com/arti-339835-marah.html

Marimba, Ahmad D, 1980. Pengantar Filsafat Pendidikan Islam,Bandung : PT al-Ma'arif.

Muhaimin, 2005, Pengembangan Kurikulum Pendidikan Agama Islamdi sekolah, Madrasah, dan Perguruan tinggi, Jakarta : PT Raja Grafindo Persada.

Muslim, Șah̄inh Muslim, Juz 2, al-Maktabah al-Syāmilah, alMaktabah al-Ta'āwunī wa al-Da'wah bi al-Rauḍah, t.th.

Muslim, Sah̄̄h Muslim,, Juz 7, al-Maktabah al-Syāmilah, alMaktabah al-Ta'āwunī wa al-Da'wah bi al-Rauḍah, t.th.

Naim, Ngainun, 2011, Dasar-Dasar Komunikasi Pendidikan, Yogyakarta, Ar-ruzz Media.

Rumayis, 1994, Ilmu Pendidikan Islam, Jakarta : Kalam Mutiara. Syafe,I,Rahmat,Ilmu Ushul Fiqh Untuk IAIN, STAIN dan PTAIS, Bandung: CV.Pustaka Setia. 